\title{
The Cross Cultural Communication Of Thailand's Students in University Muhammadiyah Sidoarjo
}

\author{
$1^{\mathrm{st}}$ Kukuh Sinduwiatmo \\ Communication Study Program \\ Universitas Muhammadiyah Sidoarjo \\ Sidoarjo, Indonesia \\ kukuhsinduwiatmo@umsida.ac.id
}

\author{
$2^{\text {nd }}$ Sufiyanto \\ Communication Study Program \\ Universitas Muhammadiyah Sidoarjo \\ Sidoarjo, Indonesia \\ sufiyanto@umsida.ac.id
}

\begin{abstract}
The World of Education is so dynamic especially its development from year to year. This is coupled with the continuous development of technology, the exchange of information needs each other primarily in its participation to advance intellectual competitiveness in academia. Taking education in other countries is one of the efforts to develop desired knowledge and needed. Obtaining education in other countries is certainly not easy, there are various kinds of differences in ways of communicating and cultural differences in the countries they visit from their countries of origin. This study aims to determine the cross-cultural communication of Thailand's students at the Universitas Muhammadiyah Sidoarja. This research is a qualitative descriptive study. The technique of determining informants using purposive sampling technique, the number of informants in this study amounted to 5 informants. Data collection techniques through interviews, observation and documentation. The results of this study indicate that the cross-cultural communication of Thailand students at the Muhammadiyah Sidoarjo University has been effective. Thailand students who have not recently lived in Indonesia sometimes find it difficult to learn Indonesian. The informants have good competence in adjusting when communicating with people of different cultures.
\end{abstract}

Keywords - The Cross-Cultural Communication, Student, Education

\section{INTRODUCTION}

The dynamics especially in the world of Education are developing very rapidly, this is accompanied by the development of technology. The two synagogues are interrelated and cannot be separated either from the social or cultural side. The transformation of science is needed in an effort to increase intellectual and knowledge as a form of compensation from a world civilization. Study exchange is certainly inevitable to meet the needs of social needs, one of which is in the field of Education. Student exchange is an option for academics to see and search for several studies which according to him can help make the scientific contributions they want. Data obtained from the official website of the Ministry of Technology Research and Higher Education (DIKTI), which throughout 2016 there were 6,967 study permits issued by the Directorate of Higher Education Institutions (PT). A study permit is one of the main requirements for foreign students to obtain immigration documents in the form of student visas and limited residence permits or ITAS issued by the Directorate General of Immigration, Ministry of Law and Human Rights. Communication is a means of connecting to be able to interact for them as well as cultural transformation between the two parties even though language problems are considered as the main factor in communication. Especially foreign students from Thailand have the perception that the Melayu language with Indonesian is the same. Indonesian with a variety of local languages that are very complex with various tribes that exist, it is also part of the constraints where foreign students do not yet master Indonesian but they must be faced with the local language. Another social phenomenon brings its own questions for Thailand students, one of which is clothes worn by students of Universitas Muhammadiyah Sidoarjo, it feels a little strange to them when batik is one of the motives that is often encountered, unlike the case with Thailand students who are more dominant in the use of koko or robe when college. This has become a topic among them in order to get anything that is characteristic of life while inside and outside the campus environment.

In intercultural communication, these obstacles can be in the form of prejudice, stereotypes, and ethnocentrism. Prejudice is a person's feelings toward certain groups, races, or cultures that are different from him [1] Prejudice also overshadows in their interactions (Thailand students) where there are negative attitudes towards other groups, thus affecting their behavior towards that group. Gradually these prejudices appear to be discriminatory actions which according to him without objective reasons, that attitude is certainly an obstacle that "threatens" both himself and other groups. Stereotype is a complex form of grouping that mentally regulates one's experience and directs one's attitude in dealing with certain people [2]. This is a way to organize the images that a person has into a certain and simple category that is used to represent a group of people [3]. Ethnocentrism is a tendency to view norms and values in their cultural groups as absolute and be used as standards to measure and act on all other cultures. Their ethnocentrism creates negative prejudices and stereotypes towards other ethnic or groups. [4] Personally for Thailand students in particular the nature of building a "self-confidence" their perspective is dominantly arguably the best when viewed in terms of culture, they have a measurement value compared to culture, especially in the campus environment of the Universitas Muhammadiyah Sidoarjo (UMSIDA)

\section{RESEARCH METHOD}

This study uses a qualitative type of research targeting 6 students Of Thailand who carry out their studies at Universitas Muhammadiyah Sidoarja and 10 studens Universitas Muhammadiyah Sidoarja. Observations and interviews were 
conducted to obtain data in this study [5]. The data collected was analyzed in descriptive narrative.

\section{RESULT AND DISCUSSION}

Openness with one another manifests the effectiveness between them in communication. Openness is an attitude to be able to receive input from others, and be willing to convey important information to others. Thailand students with UMSIDA Student in communication did not experience any restrictions in conveying anything and all of them were accepted by all parties involved in communication. The application of openness to cross-cultural communication between Thailand students and UMSIDA students works effectively where they realize the differences that occur, the difference for him is not a barrier for them to continue to interact. The increasingly intertwined interaction fosters a sense of empathy from them where a process occurs when someone can feel the feelings of others and can capture the meaning of those feelings. Empathy that is built is a determining factor of effectiveness in the involvement of deep nuances of communication, even though Thailand students are a minority, but they still have a sense of caring and vice versa. The effectiveness of intercultural communication referred to as empathy here cares for one another, helps one another and shares the feelings of the person [6]. Empathy goes well after they know each other. The basic positive feeling is in the mind and action, the more it feels good, the positive energy impact [7]. It has been seen that they respect each other, Thailand students think positively so that they are always surrounded by good people and willing to accept their shortcomings.

The application of positive feelings also occurs in communication relationships every time they socialize, thus always thinking positively about the presence of new people, respecting each other, maintaining commitment so that the relationship gets better. Language which is an obstacle for Thailand students during interaction can be answered slowly with a process of confidence accompanied by positive feelings.

Language which is an obstacle for Thailand students during interaction can be answered slowly with a process of confidence accompanied by positive feelings. Some obstacles are felt by them even though there is more trust but they are very common in every introduction (adaptation) to the new environment. That is Language. Language especially for them verbal requires a long time to get intonation, meaning and meaning. Difficulties for the sake of these difficulties can be answered when they have a strong sense of confidence at the same time there is encouragement to want to learn with anyone and anywhere. On the other hand, food is something that is quite "annoying" for them while they are overseas. By deciding to own culinary is the solution for them in meeting their needs

\section{CONCLUSION}

The results revealed that the cross-cultural communication of Thailand students with students at Muhammadiyah University was as follows: (1) The communication that was established was quite effective, (2) The attitude of confidence was the capital to build deep communication, (3) Openness with each other had a function of introspection in make friends, (4) Mutual understanding of the culture that is owned.

On the otherhand they encounter an obstacle that they can slowly overcome slowly including language and food. With confidence and enthusiasm to learn with the environment it can be overcome, as well as food for them there is a difference in taste with the menu served at Indonesia.

\section{REFERENCES}

[1] Alo Liliweri, "Gatra-Gatra Intercultural Communication", Yogyakarta: Offset Student Library, 2001.

[2] Joseph A. DeVito, "Inter-Human Communication", Jakarta: Professional Books, 1996.

[3] A. Afif, "Social Identity Theory", Yogyakarta: Uii Press, 2015.

[4] Ngalimun, M.Pd., M.I.Kom, "Intercultural Communication", Yogyakarta: Student Heritage, 2018

[5] M. A. Hogg, "" Theory of Social Identity "," In Contemporary Social Psychological Theory, California, Stanford University Press, 2006.

[6] Sugiyono, Prof., Dr.., "Quantitative and Qualitative Research Methods and R\&D", Bandung: Alfabeta, 2011.

[7] Jalaluddin Rachmat, "Communication Psychology", Bandung: Simbiosa Rekatama Media, 2018 